\title{
Ethnic and HLA patterns related to multiple sclerosis in Wellington, New Zealand
}

\author{
DH MILLER, RW HORNABROOK, J DAGGER, ${ }^{*}$ R FONG* \\ From the Departments of Neurology and Immunohaematology, ${ }^{*}$ Wellington Hospital, Wellington, New \\ Zealand
}

SUMmARY A recent survey revealed 237 cases of multiple sclerosis in Wellington, New Zealand, giving an overall prevalence of 69 cases per 100,000. Two hundred and thirty-five were European with one Asian and only one Maori, confirming the rarity of the disease in Maoris. HLA A3, B7 and DR2 antigens were more frequent in multiple sclerosis patients compared with European controls. The same antigens were much less common in the Maori population. The results suggest that Maoris have a low susceptibility to multiple sclerosis despite living in a high risk area, and that genetic susceptibility may be related to the HLA system.

New Zealand is generally regarded as an area of high prevalence for multiple sclerosis. ${ }^{2}$ Within this general statement there is evidence from hospital admission and mortality data of a two to three fold difference between the southern area of the South Island (latitude $46^{\circ} \mathrm{S}$ ) and the northern area of the North Island (latitude $37^{\circ} \mathrm{S}$ ), the highest figures being in the South.'

HLA patterns in multiple sclerosis have been fully reviewed. ${ }^{34}$ There has been a consistent increase in the frequency of A3, B7 and DR2 antigens in European populations of Northern Europe, North America and Australia. This is most striking for DR2 which is present in 40 to $70 \%$ of patients with multiple sclerosis as against 16 to $28 \%$ of controls. This association has not been present in Jewish and Japanese patients.

A low frequency of A3, B7 and DR2 has been reported in Maoris ${ }^{5}$ and Cook Islanders. ${ }^{6}$ It has been our clinical impression that multiple sclerosis is uncommon in the Maori and Pacific Island Polynesian. This impression, if confirmed, would be of particular interest in the Maori who has lived in New Zealand since pre-European times. This study reports on the ethnic pattern of multiple sclerosis in Wellington and compares the HLA pattern of multiple sclerosis patients with European and Maori controls.

Address for reprint requests: Dr DH Miller, National Hospitals for Nervous Diseases, Queen Square, London WC1N 3BG, UK.

Received 30 November 1984 and in revised form 22 March 1985. Accepted 12 June 1985

\section{Background information}

The largest ethnic group in New Zealand is the European which accounts for over $85 \%$ of the total population of approximately 3.2 million. European settlement of New Zealand dates from the early nineteenth century, with the great majority of settlers coming from the United Kingdom. The second largest ethnic group is the New Zealand Maori, who has lived in New Zealand for a much longer time and who currently constitutes $9 \%$ of the total population.' The third largest group is the Pacific Island Polynesian. ${ }^{7}$ Most of this group have migrated in recent decades from Samoa, Cook Islands and other Pacific Islands in Polynesia. This group has settled largely in the North Island cities, in particular Auckland. The Wellington region, which is the area covered by the present study, is at the southern end of the North Island (latitude $41^{\circ} \mathrm{S}$ ) and had a usually resident population in the 1981 census of 341,454 including 22,830 Maoris and 15,819 Pacific Island Polynesians.?

The age structure of the three main ethnic groups shows an important difference. The European has an older age distribution than the Maori and Pacific Islander. In Wellington $66 \%$ of Europeans are aged 20 years or more compared with $50 \%$ of Maoris and $49 \%$ of Polynesians. ${ }^{7}$ This difference is taken into account when calculating an "expected" number of multiple sclerosis cases in the Maori and Polynesian group (see table 2). There is also a difference in the geographical distribution of the three main ethnic groups. Seventy three per cent of the total population lives in the North Island and $27 \%$ in the South. However $93 \%$ of Maoris and $95 \%$ of Polynesians live in the North Island. ${ }^{7}$

\section{Methods}

Cases were obtained from hospital and neurological department records, neurologists' rooms, and the Welling- 
ton multiple sclerosis Society. Cases seen during the previous survey of Hornabrook' were traced and reviewed. The exact area of study in which patients had to be normally resident was the Wellington Statistical Division upon which census figures are also enumerated. This incorporates Wellington City, Hutt Valley, Porirua basin and Kapiti coast as far as Waikanae. Each patient was examined by one of the authors (DHM or RWH) and all available medical data was reviewed. Cases were classified according to a simplification of the criteria established by McDonald and Halliday. ${ }^{8}$ Our cases of definite or probable multiple sclerosis included the classes clinical definite, early probable or latent, and progressive probable. Our possible cases included the classes progressive possible and suspected multiple sclerosis.

The prevalence date for the study was 30 June 1983. Calculation of disease prevalence was based on the 1981 census population figures for the Wellington Statistical Division. These can be accepted as closely approximating the actual population of 30 June 1983 as the Wellington region has shown minimal changes in its population in recent years.

Cases were classified according to ethnic group. A Maori was defined as having at least $50 \%$ Maori blood, this also being the criterion for the 1981 census population figures. A European was defined as having at least $75 \%$ European blood.

HLA typing was performed on most patients. HLA A and $B$ typing was performed on peripheral blood lymphocytes using the standard NIH lymphocytotoxicity test." HLA DR typing was carried out on nylon wool purified B lymphocytes using the prolonged NIH lymphocytotoxicity test. $^{10}$

\section{Results}

On 30 June 1983 there were 237 known cases of multiple sclerosis living in the Wellington area. Of these 198 were classified as definite or probable multiple sclerosis, with 39 possible cases. Thus the prevalence for all cases is 69 per 100,000 and for definite/probable cases is 58 per 100,000 making Wellington an area of high prevalence for the disease.

Cases were classified according to ethnic origin (table 1)." There were 235 Europeans, one Maori and one Asian. Amongst Europeans there is a prevalence of 80 per 100,000 for all cases and 68 per 100,000 for definite or probable cases. Multiple sclerosis appears rare in all non-European ethnic groups although the population size of Asians and Indians under study is very small. Assuming an equal disease frequency for each ethnic group we would expect 203 European, 16 Maori, 11 Polynesian, three Asian and two Indian cases in making up the total of 237 cases (table 1). However, as the prevalence of multiple sclerosis varies markedly with age, correction must be made for the important difference in the age structure of the three main ethnic groups (table 2). Assuming an equal disease frequency amongst the three groups for each decade (table 2) we would expect 12 Maori and eight or nine Polynesian cases. The one Maori case recorded was a 23-year-old male with a slowly progressive spastic paraparesis. A family history was unavailable as the patient was adopted. The patient was unwilling to have evoked potentials or CSF examination. $\mathrm{He}$ was classified as a possible case only.

HLA typing (table 3) revealed a higher frequency of A3, B7 and DR2 antigens in multiple sclerosis patients compared with European controls. This was most pronounced for DR2 which was present in $63 \%$ of patients versus $30 \%$ of European controls DR2 was present in only 7\% of Maori controls while $\vec{\omega}$ A3 and B7 were also about a fifth as common as if European controls. A1, B8, B12, DR1 and DR were more frequent in Europeans (patients and cone trols) than Maoris, while Maoris had a higher free quency of A9, B16, Bw22 and DR5.

\section{Discussion}

Theories of causation of multiple sclerosis generally o acknowledge environmental and genetic factors. ${ }^{12}$ Strong evidence for an environmental factor comes from the demonstration that disease frequency varies with latitude in Europeans, ${ }^{13-16}$ and with the evidence of disease "epidemics". ${ }^{17}$ There is evidence $\frac{\circ}{D}$ from migration studies that such a factor is acquired in the first 15 years of life..$^{18} \mathrm{~A}$ genetic factor is suggested by the rarity of multiple sclerosis in Japanese who live at the same latitude as commonly affected Europeans, ${ }^{19}$ and by evidence of a higher concordance rate for multiple sclerosis in monozygotic as against dizygotic twins. ${ }^{20}$

Table 1 Multiple sclerosis cases in Wellington according to ethnic group

\begin{tabular}{lccc}
\hline Ethnic group & Population" & Actual number of cases & "Expected" number of cases \\
\hline European & 293.287 & 235 & 203 \\
Maori & 22,830 & 1 & 16 \\
Pacific Island & 15,819 & 0 & 11 \\
Polynesian & 4,218 & 1 & 3 \\
Asian & 2,778 & 0 & 2 \\
Indian & 2,522 & 0 & 2 \\
All other ethnic groups & 341,454 & 237 & 237 \\
Total & & & \\
\hline
\end{tabular}


Table 2 The "expected" number of multiple sclerosis cases in Maoris and Pacific Island Polynesians assuming an equal disease frequency with Europeans for each age group by decade (in Wellington, New Zealand)

\begin{tabular}{|c|c|c|c|c|c|c|}
\hline $\begin{array}{l}\text { Age group } \\
\text { (ys) }\end{array}$ & $\begin{array}{l}\text { European* } \\
\text { population }\end{array}$ & $\begin{array}{l}\text { European cases } \\
\text { of multiple } \\
\text { sclerosis (no.) }\end{array}$ & Maori population & $\begin{array}{l}\text { “Expected” no. of } \\
\text { Maori cases of } \\
\text { multiple sclerosis }\end{array}$ & $\begin{array}{l}\text { Polynesian } \\
\text { population }\end{array}$ & $\begin{array}{l}\text { "Expected" no. of } \\
\text { Polynesian cases of } \\
\text { multiple sclerosis }\end{array}$ \\
\hline $\begin{array}{l}\text { Less than } 20 \\
20-29 \\
30-39 \\
40-49 \\
50-59 \\
60-69 \\
70-79 \\
\text { Total }\end{array}$ & $\begin{array}{r}101,259 \\
52,351 \\
44,067 \\
32,421 \\
31,589 \\
23,826 \\
14,319\end{array}$ & $\begin{array}{r}0 \\
22 \\
61 \\
61 \\
55 \\
30 \\
6 \\
235\end{array}$ & $\begin{array}{r}11,475 \\
5,178 \\
2,910 \\
1,893 \\
933 \\
339 \\
93\end{array}$ & $\begin{array}{l}0 \\
2 \cdot 3 \\
4 \cdot 2 \\
3 \cdot 6 \\
1 \cdot 6 \\
0 \cdot 4 \\
0 \cdot 1 \\
12 \cdot 2\end{array}$ & $\begin{array}{r}8,100 \\
3,095 \\
2,514 \\
1,257 \\
519 \\
249 \\
72\end{array}$ & $\begin{array}{l}0 \\
1.4 \\
3 \cdot 6 \\
2.4 \\
0.9 \\
0.3 \\
0 \\
8 \cdot 6\end{array}$ \\
\hline
\end{tabular}

*This population actually represents the total non Maori, non Polynesian population for each age group, as age group figures are only available for (1) the total population (2) Maoris and (3) Pacific Island Polynesians. About $97 \%$ of this population is European.

Table 3 HLA antigen frequencies (\%) for European patients and controls, Maori controls in Wellington

\begin{tabular}{|c|c|c|c|}
\hline & $\begin{array}{l}\text { Multiple sclerosis } \\
\text { patients* } \\
\text { (no. = 192) }\end{array}$ & $\begin{array}{l}\text { European } \\
\text { controls } \ddagger \\
(\text { no. }=185)\end{array}$ & $\begin{array}{l}\text { Maori controls } \\
\text { (no. }=79)\end{array}$ \\
\hline $\begin{array}{l}\text { A1 } \\
\text { A3 } \\
\text { A9 } \\
\text { B7 } \\
\text { B8 } \\
\text { B12 } \\
\text { B16 } \\
\text { BW22 } \\
\text { DR1 } \\
\text { DR2 } \\
\text { DR5 } \\
\text { DR7 } \\
\text { DRW8 }\end{array}$ & $\begin{array}{r}33 \\
31 \\
16 \\
43 \\
21 \\
27 \\
4 \\
3 \\
16 \\
63 \\
10 \\
20 \\
\dagger\end{array}$ & $\begin{array}{r}27 \\
24 \\
14 \\
28 \\
24 \\
26 \\
6 \\
7 \\
28 \\
30 \\
7 \\
30 \\
\dagger\end{array}$ & $\begin{array}{r}7 \\
4 \\
56 \\
6 \\
10 \\
8 \\
21 \\
38 \\
4 \\
7 \\
36 \\
3 \\
25\end{array}$ \\
\hline
\end{tabular}

The antigens listed are those where frequency differences were most apparent.

*DR typing was performed on 183 patients.

†Figures for DRW8 were not established for the European groups. $\ddagger$ Calculated from unrelated healthy laboratory staff and blood donors, Wellington Hospital.

Our study confirms a high prevalence of multiple sclerosis in Wellington, New Zealand. However the condition was uncommon in non-European ethnic groups in the area of study. The number of Asians and Indians under study is too small to make reliable conclusions regarding the frequency of the disease in these groups. It appears however that the disease is genuinely rare in Maoris and Pacific Island Polynesians. With a calculation based on age specific prevalence rates we would have expected to see 12 Maori and eight or nine Polynesian cases of multiple sclerosis assuming an equal disease frequency with Europeans. The question of why the disease is rare in these two groups must address the influence of environmental and genetic factors for each group.

Maoris: This ethnic group has lived alongside the European throughout the period of European settlement and hence has always lived in an environment which has a known high risk for developing multiple sclerosis. One does however need to take account of latitudinal differences in the distribution of the European and Maori populations. A relatively higher percentage of the Maori population has always lived in the northern part of New Zealand, an area where the risk of developing multiple sclerosis may be lower. ${ }^{1}$ It is possible then that the present Wellington Maori population has a higher proportion than its European counterpart who were resident in a lower risk area during childhood (the time at which exposure to the hypothetical environmental factor may occur). This is unlikely however to be of much significance as multiple sclerosis is still commonly seen in the northern parts of the country. With regard to genetic factors the HLA results are interesting. The HLA pattern found in our European multiple sclerosis population is very similar to that seen in other Northern European groups. A3, B7 and DR2 are linked antigens and it is not surprising that they are increased together. It has been suggested that there is a multiple sclerosis susceptibility gene on the sixth chromosome in linkage disequilibrium with the HLA system. ${ }^{21}{ }^{22}$ The very low frequency A3, B7 and DR2 antigens in Maoris would be consistent with the idea that the Maori does not carry such a gene.

Pacific Island Polynesians: Studies on Cook Island Polynesians reveals a similar HLA pattern to the Maori. ${ }^{6}$ Hence a genetic factor probably has a protective value for this ethnic group. However most Pacific Islanders have migrated to New Zealand as adults in recent decades and the possibility exists that they have not been exposed to an environmental factor at the critical age. The relative significance of genetic and environmental factors in this population is not clear at this time.

In conclusion, it would appear that multiple sclerosis is distinctly uncommon in Maoris despite the fact that they have always lived in a high risk area. A low frequency in Maoris of the HLA antigens that have been associated with multiple sclerosis in Europeans supports the conclusion that 
Maoris are genetically protected from developing multiple sclerosis.

We are grateful to the Multiple Sclerosis Society of New Zealand, who supported the study with a generous grant.

\section{References}

' Hornabrook RW. The prevalence of multiple sclerosis in New Zealand. Acta Neurol Scand 1971;47:426-38.

${ }^{2}$ Cunningham JAK. The prevalence of disseminated sclerosis in Christchurch. NZ Med J 1972;76:417-8.

${ }^{3}$ Batchelor JR, Compston A, McDonald WI. The significance of the association between HLA and multiple sclerosis. $\mathrm{Br}$ Med Bull 1978;34:279-84.

${ }^{4}$ Tiwari JL, Morton NE, Lalouel JM, et al. Multiple sclerosis. Joint Report. In: Terasaki PI, ed. Histocompatibility Testing 1980. Los Angeles: UCLA Tissue Typing Laboratory, 1980:687-92.

${ }^{5}$ Fong R, Dagger J, Locke H. Analysis of HLA, A, B, C and DR antigens in New Zealand Maoris. In: Simons MJ, Tait BD, eds. Proceedings of the Second Asia and Oceanic Histocompatibility Workshop Conference. Melbourne: Immunopublishing, 1983:272-5.

${ }^{6}$ Roberts MW, Minnee KE, Woodfield DG. HLA antigens in Cook Islanders. In: Simons MJ, Tait BD, eds. Proceedings of the Second Asia and Oceanic Histocompatibility Workshop Conferences. Melbourne: Immunopublishing, 1983:261-71.

7 Department of Statistics, Wellington. Population census of 1981. Age distribution by statistical divisions for total population, New Zealand Maoris and usually resident Pacific Island Polynesians. Wellington: Government Printer, 1983.

${ }^{8}$ McDonald WI, Halliday AM. Diagnosis and classification of multiple sclerosis. Br Med Bull 1977;33:4-8.

${ }^{y}$ Terasaki PI, McClelland JC, Park MS, et al. Microdroplet lymphocyte cytotoxicity test. Manual of tissue typing techniques. Washington DC: DHEW Publication (NIH) Government Printing Office,
$1973 ; 74: 545$

${ }^{10}$ Danilovs JA, Ayoub G, Terasaki PI. B-lymphocyte isolation by thrombin-nylon wool. In: Terasaki PI, ed. Histocompatibility Testing 1980. Los Angeles: UCLA Tissue typing laboratory, 1980:277-88.

" Department of Statistics, Wellington. Population census of 1981. Ethnic origin by statistical division for the usually resident population. 1983;7:83. Government Printer.

${ }^{12}$ McDonald WI. Multiple Sclerosis: the present position. Acta Neurol Scand 1983;68:65-76.

${ }^{13}$ Kurland LT, Mulder DW, Westlund KB. Multiple Sclerosis and Amyotrophic Lateral Sclerosis. Etiologic significance of recent epidemiologic and genetic studies. $N$ Engl J Med 1955;252:649-53.

${ }^{14}$ Alter M, Alison RS, Rhett Talbett O, Kurland LT. Geographic distribution of multiple sclerosis. World Neurol 1960; 1:55-70.

15 Sutherland JM, Tyrer JH, Eadie MJ. The prevalence of multiple sclerosis in Australia. Brain 1962;85:149-64.

${ }^{16}$ McCall MG, Brereton T Le G, Dawson A, Millengen K, $\vec{\circ}$ Sutherland JM, Acheson ED. Frequency of multiple $\vec{A}$ sclerosis in three Australian cities-Perth, Newcastle $\omega$ and Hobart. J Neurol Neurosurg Psychiatry 1968; 31:1-9.

${ }^{17}$ Kurtzke JF, Hyllested K. Multiple sclerosis in the Faeroe Islands: I. clinical and epidemiological features. Ann Neurol 1979;5:6-21.

${ }^{18}$ Deans G, Kurtzke JF. On the risk of multiple sclerosi according to age at immigration to South Africa. $B$ Med J 1971;3:725-9.

${ }^{19}$ Kurtzke JF. A reassessment of the distribution of mult? $\rightarrow$ ple sclerosis. Part One. Acta Neurol Scand 1975;5隹 110-36.

${ }^{20}$ Williams A, Eldridge A, McFarland H, Houff S, Kretes H, McFarlin D. Multiple sclerosis in twins. Neurolog (Minneap) 1980;30:1139-47.

${ }^{21}$ Stewart GJ, McLeod JG, Basten A, Bashir HV. HLÄ family studies and multiple sclerosis: a common gene dominantly expressed. Hum Immunol 1981;3:13-29.

22 Tiwari JL, Hodge SE, Teresaki DT, Spence MA. HLA and the inheritance of multiple sclerosis: linkage analysis of 72 pedigrees. Am J Hum Genet 1980;32:103-11. 